\title{
Assessment of Efficacy and Effectiveness of Some Extracted Bio-Chemicals as Bio-Fungicides on Wood
}

\section{Procjena učinkovitosti i djelotvornosti ekstrahiranih biokemikalija kao fungicida za drvo}

Original scientific paper • Izvorni znanstveni rad

Received-prispjelo: 27. 8. 2018.

Accepted-prihvaćeno: 20. 11. 2019.

UDK: $630 * 841.513 ; 630 * 874 ; 630 * 874.11$

https://doi.org/10.5552/drvind.2019.1837

\begin{abstract}
The present study investigates in-vitro the antifungal activity of two extracts (ethyl ether extracts of Schinus terebinthifolius ripened fruits and Pinus rigida heartwood) and two essential oils (Thymus vulgaris and Origanum majorana leaves) against two species of fungi; Trichoderma harzianum and Aspergillus niger. The results clearly show that $\underline{O}$. majorana oil and $\underline{\text { P. rigida }}$ wood extract had the highest activity against both fungi and were chosen for the application on four wood species; Weeping-Wreath Wattle (Acacia saligna), Beech (Fagus sylvatica), Black Walnut (Juglans nigra) and Pitch Pine (Pinus rigida). Additionally, their impact on the wood structure was examined by FTIR, SEM and colorimetry. The study suggests that $\underline{O}$. majorana oil appears to show the best results and could be used as friendly bio-fungicides to protect wood objects without changing their structures.
\end{abstract}

Keywords: bio-fungicides, wood, essential oils, extracts, antifungal activity

SAŽETAK • U studiji je opisano istraživanje in vitro protugljivičnog djelovanja dvaju ekstrakata (etil eterskih ekstrakata iz zrelog ploda drva Schinus terebinthifolius $i$ iz srži drva Pinus rigida) $i$ dvaju esencijalnih ulja (iz lišća drva Thymus vulgaris $i$ iz drva Origanum majorana) na dvije vrste gljiva, Trichoderma harzianum $i \underline{\text { Asper- }}$

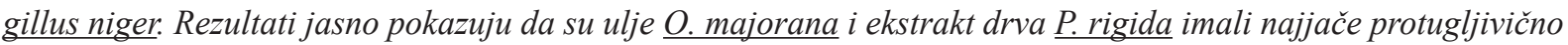
djelovanje na obje vrste gljiva te su zato odabrani za primjenu na četiri vrste drva: drvu akacije (Acacia saligna), drvu bukve (Fagus sylvatica), drvu crnog oraha (Juglans nigra) i drvu bora (Pinus rigida). Ujedno je uz pomoć FTIR-a, SEM-a i kolorimetrije ispitan utjecaj tih ekstrakata i ulja na strukturu drva. Istraživanje pokazuje da su najbolji rezultati postignuti uljem iz lišća drva O. majorane i da se ono može upotrijebiti kao ekološki biofungicid za zaštitu drvenih predmeta, bez promjene strukture drva.

Ključne riječi: biofungicidi, drvo, esencijalna ulja, ekstrakti, protugljivično djelovanje

\footnotetext{
${ }^{1}$ Authors are associate professor at Alexandria University, Faculty of Agriculture (EL-Shatby), Forestry and Wood Technology Department, Alexandria, Egypt. ${ }^{2}$ Author are professors at Cairo University, Faculty of Archaeology, Conservation Department, Giza, Egypt.

Autor je izvanredni profesor Sveučilišta Aleksandrija, Agronomski fakultet (EL-Shatby), Zavod za šumarstvo i drvnu tehnologiju, Aleksandrija, Egipat. ${ }^{2}$ Autori su profesori Sveučilišta Kairo, Arheološki fakultet, Zavod za konzervaciju, Giza, Egipat.
} 


\section{INTRODUCTION}

\section{UVOD}

Natural products such as essential oil (EO) and extracts have been extensively used in many works as wood bio-fungicides treatment against the growth of mold fungi (Al-Huqail et al., 2019; Behiry et al., 2019; Salem et al., 2019a, b). Molds can grow over the surface of wood, wooden products and other organic materials, and consume carbohydrates, and other simple sugars resulting in chemical and morphological changes of the material structure as well as leaving stains (Kerner-Gang and Schneider, 1969; Blanchette et al., 1992; Zabel and Morrell, 1992; Fabbri et al., 1997; Breuil, 1998; Hamed, 2013; Mansour and Salem, 2015; Xu et al., 2015; Mesquita et al., 2009; Salem, 2016; Salem et al., 2016a,b; Hamed and Mansour, 2018). They can use proteins and triglycerides by colonizing ray parenchyma and cell lumen of sapwood (Breuil, 1998). Also, dark grey discoloration could be seen on wood surface as Alternaria and other molds grow (Domsch et al., 2007).

Deteriorated wooden sculptures (Fazio et al., 2011) and art photographs stored in the quarantine room of the Cultural Center of Belgrade have shown the presence of Trichoderma viride, Chaetomium globosum, Aspergillus niger and Alternaria sp. with proven cellulolytic activity (Ljaljević Grbić et al., 2013). Pigments and colored spores are produced as the molds grow on wood surfaces resulting in wood discolorations (Viitanen and Ritschkoff, 1991; Ghosh et al., 2008), and distortion of wood could take place without affecting its strength (Daniel, 2003). Decayed bookbinding leather showed the prescience of C. globosum as a very active organism (Strzelczyk et al., 1987).

Nevertheless, natural durability of some woods has been achieved because of extractives presence i.e., tannins could prevent the growth of Trametes versicolor and Serpula lacrymans (Jeloková and Šindler, 1997). The presence of phenolic extractives and hydrophobic properties in tone pine (Pinus pinea) heartwood was linked to the higher durability against wood-decaying fungi (De Angelis et al., 2018).

The existence of sugars in beech wood, for example, is responsible for the fungal attack (Jeloková and Šindler, 2001). Furthermore, the elemental composition of some wood species, Pinus rigida, Juglans nigra, and Fagus sylvatica, Citharexylum spinosum and Morus alba, changed after inoculation with Penicillium selerotigenum, Paecilomyces variotii, and Aspergillus niger (Mansour et al., 2015a; Salem, 2016). Other studies reported that the aging factors act synergistically to have a more prominent influence on less durable-wood compared to durable or preservativetreated wood (Žlahtič and Humar, 2017). Also, there is a strong correlation between the moisture content of the cell wall and the ability of microorganisms to degrade wood (Schmidt, 2006; Van Meel et al., 2011; Meyer and Brischke, 2015).

Bio-products have a broad application as wood preservatives against the growth of mold and decay fungi. They are green alternatives for the synthetic fun- gicides, since they are sustainably resourced and ecofriendly with extremely low toxicity to human beings and wooden artifacts (Philp et al., 1995; Verma and Dubey, 1999; Qi and Jellison, 2004; Wang et al., 2005; Kiran and Raveesha, 2006; Li et al., 2013).

Recently, a wide range of research has been done on the antifungal activity of the natural extracts against the growth of fungi. EO of Pinus rigida wood at 5000 ppm showed complete inhibition against the growth of A. alternata, Fusarium subglutinans, C. globosum, and $A$. niger, while good inhibitions against $C$. globosum at 5000 ppm was found by applying the EO from Eucalyptus camaldulensis leaves (Salem et al., 2016a). Wood specimens treated at the level of $2 \%$ concentration of $P$. rigida heartwood extract showed good inhibition to mold growth under laboratory conditions (Salem et al., 2016b). The combination of Paraloid B-72 and the methanolic extract of $C$. sempervirens wood might be used as a potential biocide against $T$. harzianum (Mansour and Salem, 2015).

This study aims to assess the efficacy of some bio-fungicides in fungi inhibition and their impact on the anatomical structure and chemical composition of wood after treatment and aging.

\section{MATERIALS AND METHODS \\ 2. MATERIJALI I METODE}

\subsection{Plant extracts and essential oils}

2.1. Biljni ekstrakti i esencijalna ulja

Ripened fruits of Schinus terebinthifolius were collected from Alexandria, Egypt, while Pinus rigida heartwood was provided from wood sawmill (Alexandria, Egypt). Thymus vulgaris and Origanum majorana leaf essential oils were bought from the National Research Center, Cairo, Egypt. About $30 \mathrm{~g}$ from each of $S$. terebinthifolius fruits and $P$. rigida heartwood were soaked with $100 \mathrm{ml}$ of ethyl ether for seven days (Salem et al., 2013), and then filtrated using filter paper (Whatman no. 1). The solvent was evaporated under reduced pressure using rotary evaporator apparatus to concentrate the extract. Extracts and essential oils were stored in sealed tubes until use.

\subsection{Chemical analysis of essential oils/extracts by Gas Chromatography-Mass Spectrometry (GC-MS)}

2.2. Kemijska analiza esencijalnih ulja/ekstrakata plinskom kromatografijom s masenom spektrometrijom (GC-MS)

Chemical compositions of essential oils and extracts were analyzed using Focus GC-DSQ Mass Spectrometer (Thermo Scientific, Austin, TX) with a direct capillary column TG-5MS $(30 \mathrm{~m} \times 0.25 \mathrm{~mm} \times 0.25$ $\mu \mathrm{m}$ film thickness) apparatus located at the Atomic and Molecular Physics Unit, Experimental Nuclear Physics Department, Nuclear Research Center, Egyptian Atomic Energy Authority, Inshas, Cairo, Egypt. The program temperature and column conditions for the separation of compounds can be found in previous published works (Salem et al., 2016c; Mohamed et al., 2019; Salem et al., 2019a, b). 
The chemical constituents of extracts were identified based on MS library searches (NIST and Wiley), and by comparing with the MS literature data (NIST, 2011; Oberacher, 2011). GC/MS contains Xcalibur 3.0 data system-type threshold values for matching factors of Standard Index (SI) and Reverse Standard Index (RSI) for confirmation of all the mass spectra (MS) appended to the library. The match factor of getting MS and the library spectrum (LS) is called SI, while the match factor of getting MS and the LS, ignoring all peaks that are not in the LS, is called RSI. The values of these two standards were obtained from the mass spectrometer data base (Salem et al., 2019b).

\subsection{In-vitro antifungal assay}

\subsection{In vitro protugljivično ispitivanje}

A culture of two fungi Trichoderma harzianum and Aspergillus niger was provided by the Laboratory of Microbiology, Conservation Department, Faculty of Archaeology, Cairo University, Egypt. Fungi were grown on Potato Dextrose Agar (PDA) medium at $26^{\circ} \mathrm{C}$. Extracts and EOs were prepared at the concentration of $1000,500,250$ and $125 \mu \mathrm{g} / \mathrm{ml}$ by dissolving in dimethyl sulfoxide (DMSO, $100 \%$ ), and $0.5 \mathrm{ml}$ of tween 80 was used with the oil to emulsify carrier oils in the solvent (Salem et al., 2016a). After sterilizing the PDA medium, the concentrated tested materials were added and then poured into sterilized Petri dishes. Mycelial culture discs ( $0.5 \mathrm{~cm}$ diameter) of each fungus from 7-day-old culture were put in the center of Petri dishes. All the plates were incubated at $26^{\circ} \mathrm{C}$. The diameter of fungal growth was measured when it completely covered the Petri dishes in the control. The measurement was done in triplicates (Salem et al., 2017). Inhibition percentage of mycelia growth was calculated as follows:

$$
M G I \%=\frac{A_{\mathrm{C}}-A_{\mathrm{t}}}{A_{\mathrm{C}}} \cdot 100
$$

Where the $M G I$ is mycelial growth inhibition, $A_{C}$ and $A_{t}$ are average diameters of fungal colonies of control and treatment, respectively.

\subsection{Preparation of wood samples \\ 2.4. Priprema uzoraka drva}

Wood blocks $(20 \mathrm{~mm} \times 20 \mathrm{~mm} \times 20 \mathrm{~mm})$ of $A c a-$ cia saligna sapwood (Alexandria, Egypt), as well as Juglans nigra, Fagus sylvatica, and Pinus rigida heartwood provided from wood sawmill (Alexandria, Egypt), prepared at the Laboratory of Wood Technology (Department of Forestry and Wood Technology, Faculty of Agriculture, Alexandria University, Egypt), were air-dried to a constant weight for the purpose of the present study. Each wood type samples was divided into three groups according to the application method of the selected bio-fungicides; the first one was treated by Spraying, the second one was treated by immersion and the third one was kept untreated and used for comparison. Three samples for each treatment method were evaluated in order to obtain the mean values.

\subsection{Preparation of wood samples}

2.5. Priprema uzoraka drva

Wood samples were conditioned at $20 \pm 2{ }^{\circ} \mathrm{C}$ and a relative humidity of $55 \pm 5 \%(\mathrm{RH})$ prior to and after treatment. The EOs and extracts solutions were applied on wood samples by two methods: spraying and total immersion for $10 \mathrm{~min}$ into solution at room temperature. After the treatment, samples were left to dry on metal racks for a week. After that, the untreated and treated samples were subjected to accelerated aging in Binder 924030000200 oven for humid heat aging at 80 ${ }^{\circ} \mathrm{C}$ and a relative humidity of $65 \%$ for $240 \mathrm{~h}$ at the National Institute of Standards (NIS) in Giza, Egypt. Finally, all samples were investigated.

\subsection{Weight gain with oil and extracts}

2.6. Povećanje mase $s$ uljem i ekstraktima

The penetration of the applied treatments was evaluated quantitatively based on sample weighing before and after the treatment. It was considered that the increase in mass of the treated samples was the result of the bio-fungicides uptake and retention into the wooden structure. Weight gain $\left(W G, \mathrm{~kg} / \mathrm{m}^{3}\right)$ of wood samples with oils/extracts was measured (Salem et al., 2017).

\subsection{Examination with Fourier Transform Infrared} (FTIR)

2.7. Ispitivanje infracrvenom spektroskopijom s Fourierovom transformacijom (FTIR)

FTIR spectra for wood samples, which have been treated with the chosen bio-fungicides, were measured on a Nicolet 380 FT-IR Spectrometer, in the frequency range of $4000-400 \mathrm{~cm}^{-1}$, in transmission mode using the $\mathrm{KBr}$ pellet technique at the National Institute for Standards (NIS) in Cairo, Egypt. Peak heights and width of absorption bands were measured by essential FTIR software (version 310.041).

\subsection{Examination with Fourier Transform Infrared} (FTIR)

2.8. Ispitivanje infracrvenom spektroskopijom s Fourierovom transformacijom (FTIR)

The determination of color changes due to the selected bio-fungicides was measured by using a Hunter lab colorimeter. Applying the CIE LAB color system, the color parameters $L^{*}, a^{*}$ and $b^{*}$ as well as the overall change in color indices $\left(\Delta \boldsymbol{E}^{*}\right)$ were determined in each sample before and after treatment and aging. The total color changes $\left(\Delta \boldsymbol{E}^{*}\right)$ were calculated using the following equation (George, 1995);

$$
\Delta E=\sqrt{\left(\Delta l^{*}\right)^{2}+\left(\Delta a^{*}\right)^{2}+\left(\Delta b^{*}\right)^{2}}
$$

\subsection{Environmental Scanning Electron Microscope} (ESEM)

2.9. Elektronski mikroskop za skeniranje u okolišu (ESEM)

The treated and untreated wooden samples were investigated using ESEM, Philips XL 30 at the central lab of the National Research Center in Giza, Egypt. This microscopic study was performed to monitor the penetration and changes resulting from treatment with the selected bio-fungicides within wood structure. Three samples were evaluated for each treatment.

\subsection{Statistical analysis}

\subsection{Statistička analiza}

Extracts and Eos, as well as their concentrations, were subjected to analysis of variance with two factors 
in $\mathrm{CRD}$. $\mathrm{LSD}_{0.05}$ was used for the comparison among the means of treatment. All the values are presented in mean \pm SD

\section{RESULTS AND DISCUSSION}

\section{REZULTATI I RASPRAVA}

\subsection{Chemical compositions of natural plant products \\ 3.1. Kemijski sastavi prirodnih biljnih proizvoda}

Table 1 presents chemical compounds identified in the studied essential oils or extracts. Figure 1 shows the GC/MS chromatograms of ethyl ether extract from ripened fruits of $S$. terebinthifolius (Figure 1a), T. vulgaris leaf oil (Figure 1b, c) O. majorana leaf oil (Figure 1c), and ethyl ether extract from $P$. rigida wood (Figure 1d). The major components in the ethyl ether extract of $S$. terebinthifolius fruits were oleic acid $(25.98 \%), \delta$-cadinene $(7.52 \%), \alpha$-phellandrene $(6.44$ $\%), 1 b, 5,5,6 \alpha$-tetramethyloctahydro-6H-indeno[1,2-b] oxiren-6-one $(6.10 \%)$, aromadendrene $(4.01 \%)$, hexa- decanoic acid-2,3-dihydroxypropyl ester (3.88 \%), $\alpha$-caryophyllene $(3.10 \%),(Z, Z)-9,12$-octadecadienoic acid (2.82\%), $\alpha$-bergamotene $(2.77 \%)$, dihydrohydnocarpic acid $(2.36 \%)$, and germacrene D (2.21\%). Other minor compounds, such as 9-octadecenamide (1.88 $\%)$, methyl-linolenate $(1.74 \%), \alpha$-funebrene (1.71\%), methyl-6-oxoheptanoate (1.33\%), farnesol (1.23\%), p-cymene (1.22\%), $\alpha$-methyl-linolenate $(1.15 \%)$, glucopyranosyl- $D$-glucose $(1.09 \%)$, and $D$-stachyose $(1.07 \%)$ were identified.

Recently, acetone extract of ripened fruits showed good activity against some pathogenic bacteria, the main compounds being oleic acid, $\alpha$-phellandrene, and $\delta$-cadinene (Salem et al., 2018). Bioflavonoids, free steroids, and terpenes, were also reported in S. terebinthifolius fruit extracts (Lloyd et al., 1977; Kassem et al., 2004; Lima et al., 2006).

The main compounds of $T$. vulgaris leaf essential oil (EO) were carvacrol $(9.08 \%)$, terpinen-4-ol (7.05 $\%), \boldsymbol{\gamma}$-terpinene $(5.52 \%)$, estragole ( $4.57 \%), L$-camphor $(4.50 \%)$, linalool (4.73\%), $\boldsymbol{\beta}$-caryophyllene (4.06\%),

Table 1 Chemical composition of essential oils/extracts

Tablica 1. Kemijski sastav esencijalnih ulja/ekstrakata

\begin{tabular}{|c|c|}
\hline $\begin{array}{l}\text { Essential oil/Extract } \\
\text { Esencijalna ulja/ } \\
\text { ekstrakti }\end{array}$ & Compounds / Spojevi \\
\hline $\begin{array}{l}\text { Ethyl ether extract } \\
\text { from ripened fruits of } \\
\text { S. terebinthifolius } \\
\text { etil eterski ekstrakt iz } \\
\text { zrelih plodova drva } S \text {. } \\
\text { terebinthifolius }\end{array}$ & 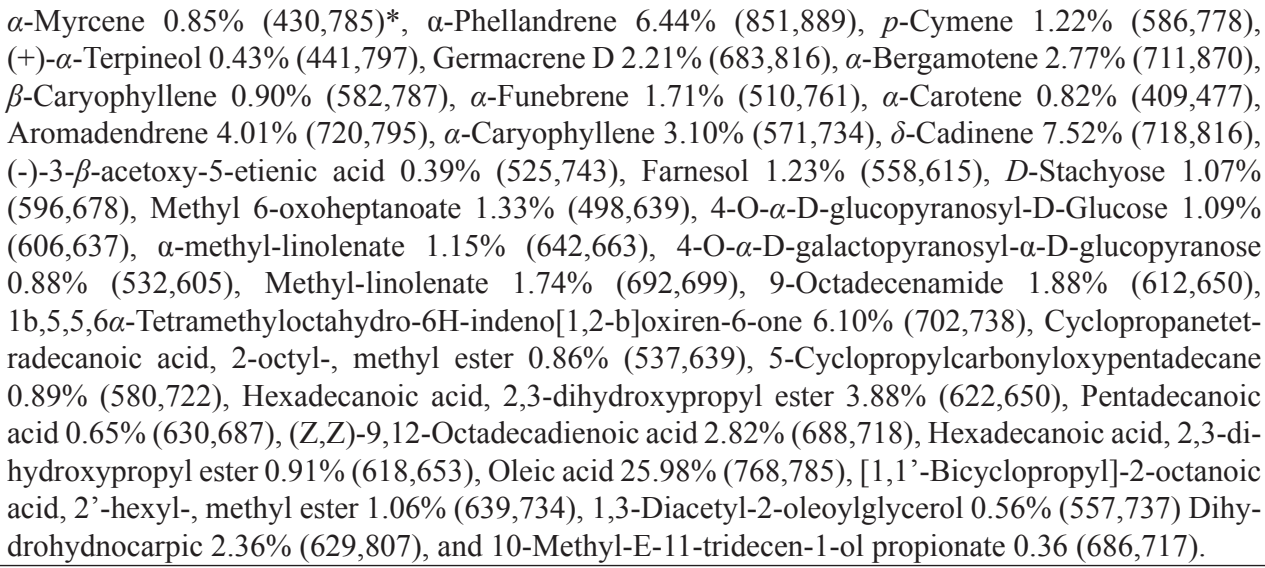 \\
\hline $\begin{array}{l}\text { T. vulgaris leaf } \\
\text { essential oil } \\
\text { esencijalno ulje iz } \\
\text { lišća drva T. vulgaris }\end{array}$ & 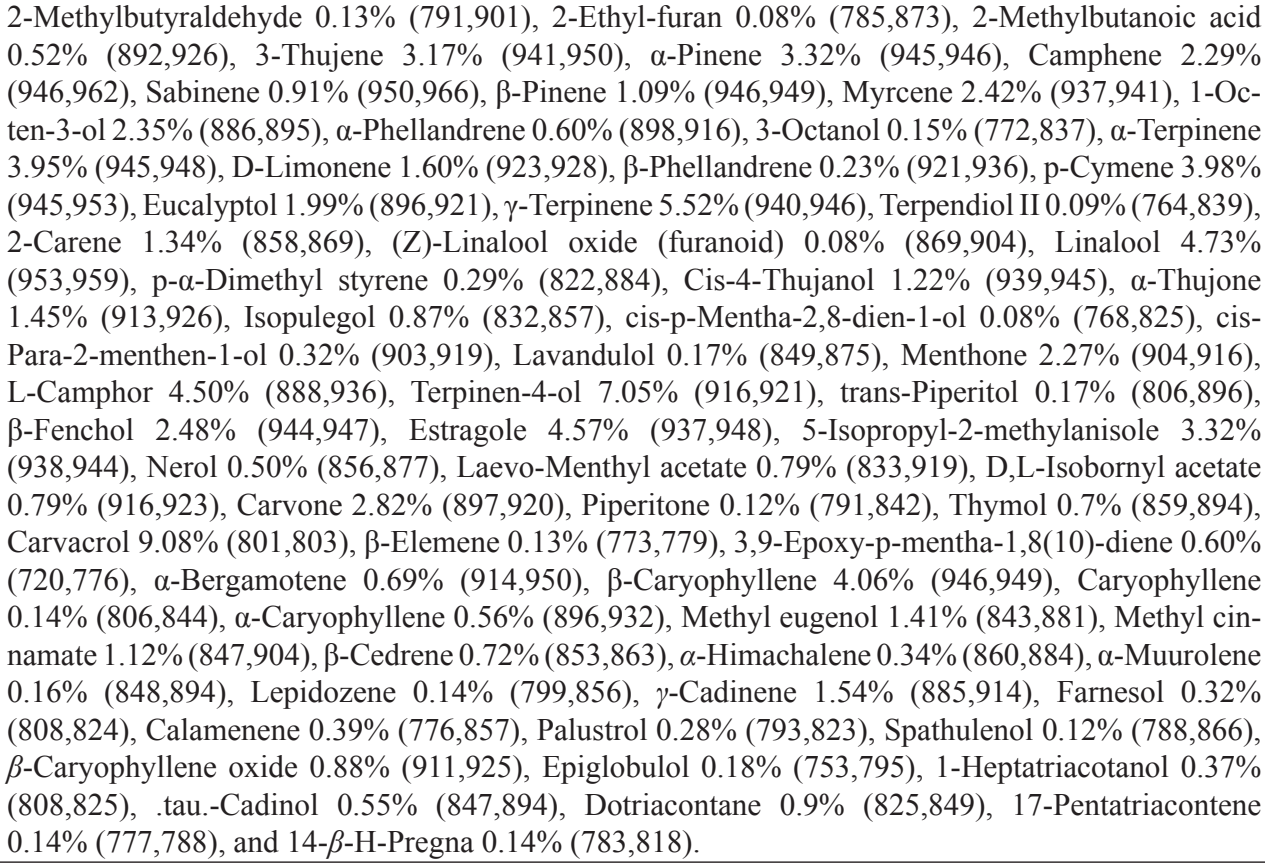 \\
\hline
\end{tabular}


Table 1 Continue

Tablica 1. Nastavak

\begin{tabular}{|c|c|}
\hline $\begin{array}{l}\text { O. majorana leaf } \\
\text { essential oil } \\
\text { esencijalno ulje iz } \\
\text { lišća drva } O . \\
\text { majorana }\end{array}$ & 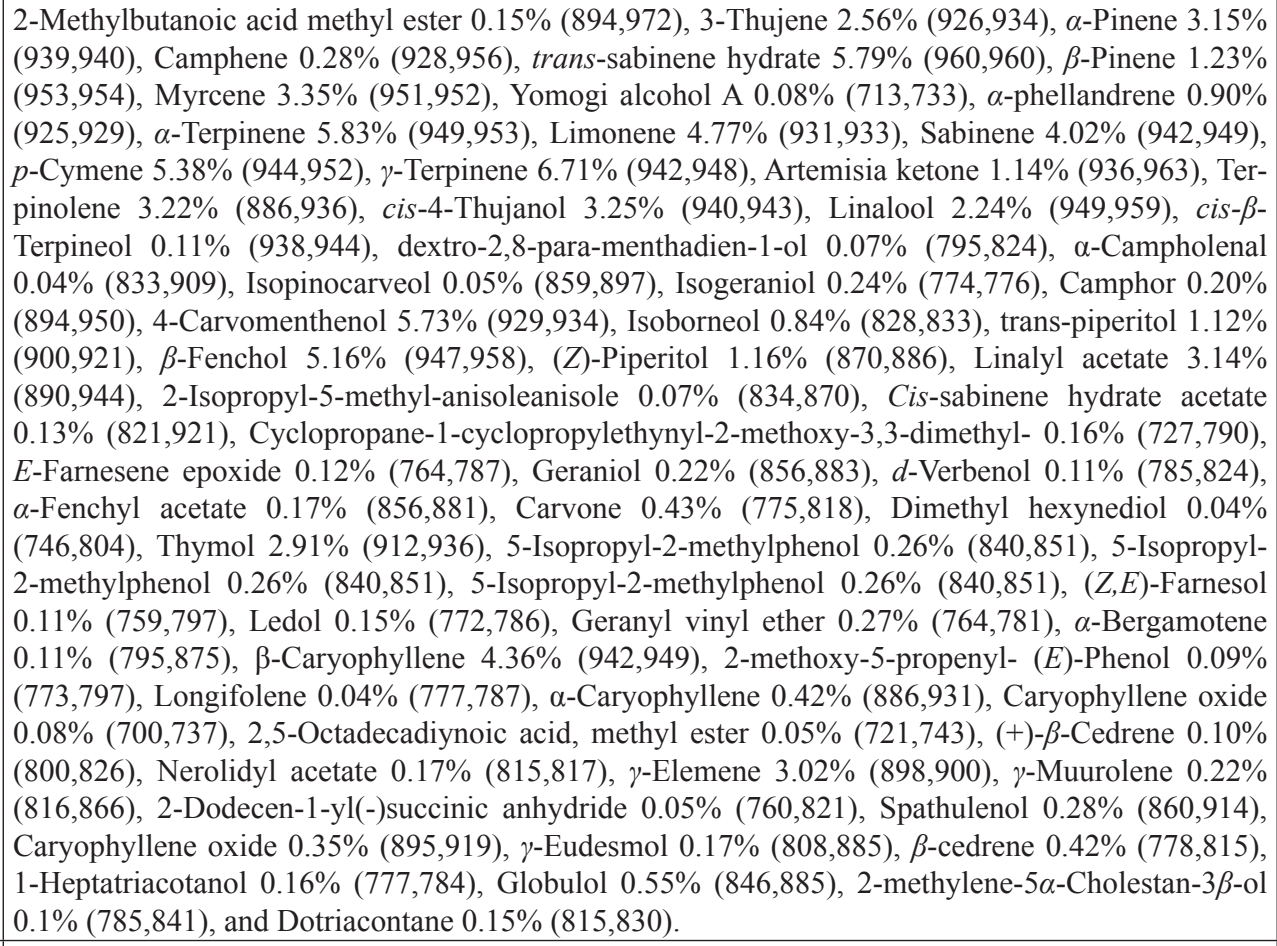 \\
\hline $\begin{array}{l}\text { Ethyl ether extract } \\
\text { from } P \text {. rigida wood } \\
\text { etil eterski ekstrakt iz } \\
\text { drva P. rigida }\end{array}$ & 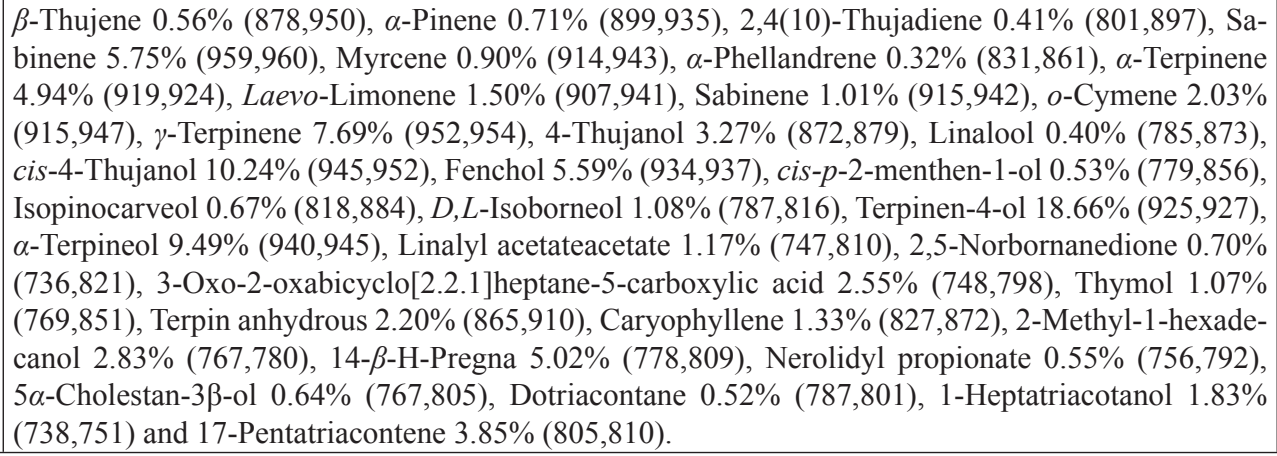 \\
\hline
\end{tabular}

* Values in parentheses are (SI: Standard Index, RSI: Reverse Standard Index). / Vrijednosti u zagradama su SI-standardni indeks, RSI-obrnuti standardni indeks.

p-cymene (3.98\%), $\boldsymbol{\alpha}$-terpinene (3.95\%), 5-isopropyl2-methylanisole (3.32\%), $\boldsymbol{\alpha}$-pinene (3.32\%), and 3-thujene $(3.17 \%)$. T. vulgaris grown in Spain with EO showed high antibacterial activity at high concentration and the oil had a high content of linaool, terpineol-4, $\boldsymbol{\gamma}$-terpinene and myrcene (Ballester-Costa et al., 2013), while in Morocco, the main components of the plant EO were camphor, camphene and $\boldsymbol{\alpha}$-pinene (Imelouane et al., 2009). In Egypt, thymol, $\boldsymbol{\gamma}$-terpinene, and $p$-cymene were the main compounds in the EO from Egyptian plant (Viuda-Martoset et al., 2010). $\alpha$-pinene, thymol and caryophyllene were the main compounds in the oil from T. vulgaris collected from Saudi Arabian market (Al-Asmari et al., 2017). Thymol and p-cymene were reported as major in T. vulgaris plants collected from Serbia (Nikolić et al., 2014).

The main compounds in leaf EO of O. majorana were 4-carvomenthenol (5.73\%), $\boldsymbol{\gamma}$-terpinene $(6.71$ $\%), \boldsymbol{\alpha}$-terpinene $(5.83 \%)$, trans-sabinene hydrate (5.79 $\%)$, $p$-cymene $(5.38 \%), \boldsymbol{\beta}$-fenchol (5.16\%), limonene (4.77\%), $\boldsymbol{\beta}$-caryophyllene (4.36\%), sabinene (4.02 $\%$ ), myrcene (3.35\%), cis-4-thujanol (3.25\%), terpin- olene (3.22\%), $\boldsymbol{\alpha}$-pinene (3.15\%), linalyl acetate (3.14 $\%)$, and $\gamma$-elemene (3.02\%).

Libyan O. majorana EO, with trans-sabinene hydrate, terpinen-4-ol, cis-sabinene hydrate and carvacrol as main compounds, was observed as a good antibacterial agent (Ibrahim et al., 2017). Romania EO of $O$. majorana showed the main compounds lynalyl acetate, $\boldsymbol{\gamma}$-terpinene and benzene (Rus et al., 2015). Trans-sabinene hydrate, terpinene-4-ol and $\gamma$-terpinene were observed in Turkish plant (Arslan and Dervis, 2010). Terpinen-4-ol, $\boldsymbol{\gamma}$-terpinene, cis-sabinene hydrate, $\boldsymbol{\alpha}$-terpinene, sabinene and $\boldsymbol{\alpha}$-terpineol were the main compounds (Busattaa et al., 2008). Terpinen-4-ol, cis-sabinene hydrate, $p$-cymene and $\gamma$-terpinene were found in the plant grown in Reunion Island (Vera and Chane-Ming, 1999), while the main constituents of the plant from Venezuelan Andes were cis-sabinene hydrate, terpinen-4-ol and $\boldsymbol{\gamma}$-terpinene (Ramos et al., 2011).

The main constitutes of wood ethyl ether extract of $P$. rigida were terpinen-4-ol (18.66 \%), cis-4-thujanol $(10.24 \%), \boldsymbol{\alpha}$-terpineol $(9.49 \%), \boldsymbol{\gamma}$-terpinene (7.69 

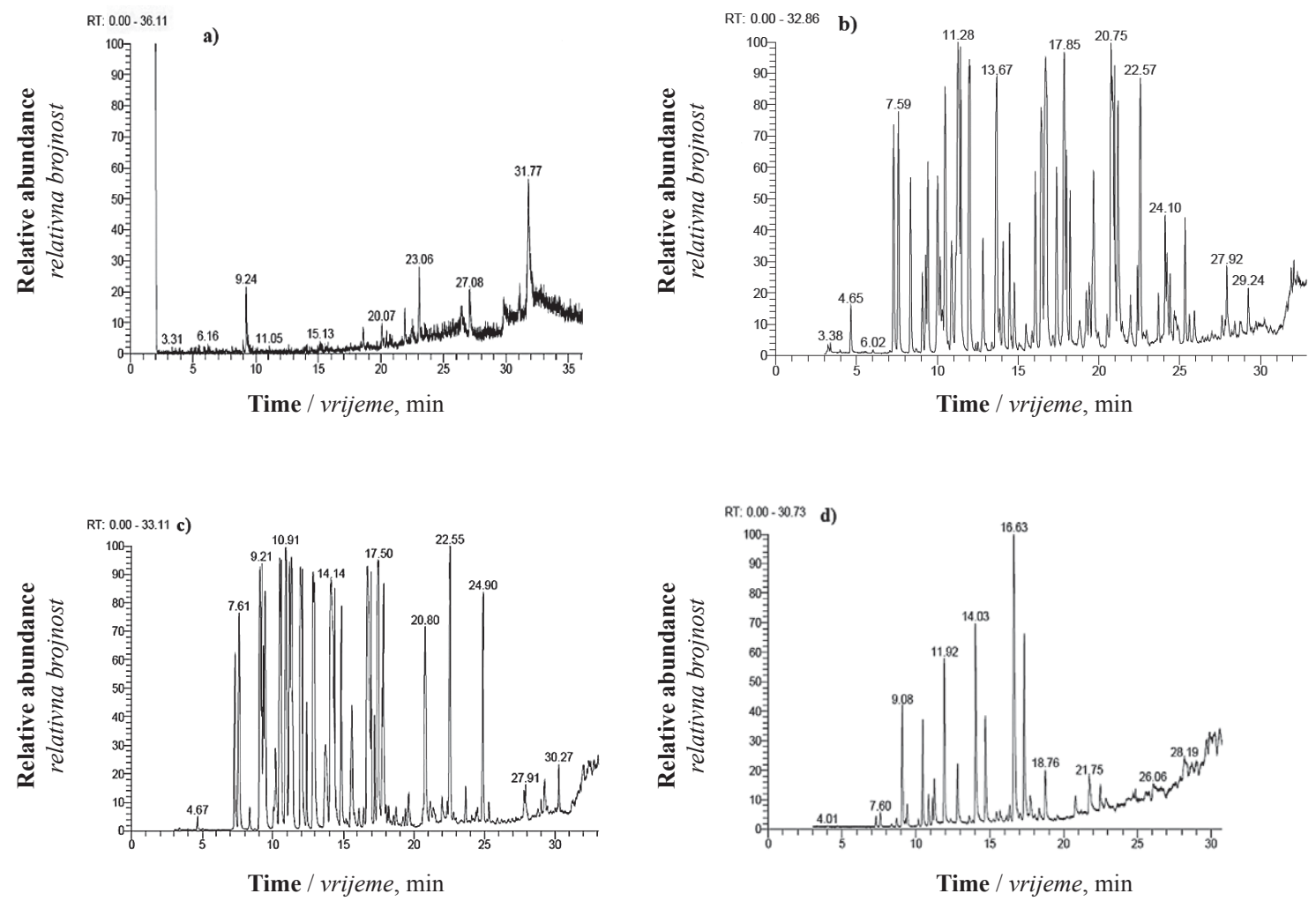

Figure $1 \mathrm{GC} / \mathrm{MS}$ Chromatograms of the studied extracts and essential oils: a) Ethyl ether extract from ripened fruits of $S$. terebinthifolius; b) T. vulgaris leaf oil; c) O. majorana leaf oil; and d) ethyl ether extract from $P$. rigida wood Slika 1. GC/MS kromatogrami istraživanih ekstrakata i esencijalnih ulja: a) etil eterski ekstrakt iz zrelih plodova drva $S$. terebinthifolius; b) esencijalno ulje iz lišća drva T. vulgaris; c) esencijalno ulje iz lišća drva O. majorana i d) etil eterski ekstrakt iz drva $P$. rigida

\%), sabinene (5.75\%), fenchol (5.59\%), 14- $\boldsymbol{\beta}$-Hpregna $(5.02 \%)$ and $\boldsymbol{\alpha}$-terpinene $(4.94 \%)$. Methanol extract $P$. rigida was found to have $\alpha$-terpineol, borneol, terpin hydrate, D-fenchyl alcohol glycol and limonene as main compounds (Salem et al., 2016b).

\subsection{Antifungal activity of extracts and essential oils}

3.2. Protugljivično djelovanje ekstrakata i esencijalnih ulja

Generally, the complete inhibition (100\%) of the tested fungi was observed with the highest concentration $(1000 \mu \mathrm{g} / \mathrm{ml})$ from all the tested EOs and extracts. According to the results reported in Table 2, O. majorana $\mathrm{EO}$ inhibited the growth of $T$. harzianum at all the concentrations tested. Also, the highest inhibition $(87.77 \%)$ of $A$. niger mycelial growth was observed with the lowest concentration of $125 \mu \mathrm{g} / \mathrm{ml}$ from $O$. majorana EO, compared to $83.33 \%, 85.55 \%$ and 4.44 $\%$, with $T$. vulgaris EO, P. rigida wood and S. terebinthifolius fruit extracts, respectively, at the same concentration.

Previously, T. harzianum showed resistance to tebuconazol (Obanda et al., 2008). T. harzianum has been reported to colonize wooden substratum (LjaljevićGrbić et al., 2013), and poles manufactured from wood treated with CCA (Wang and Zabel, 1990; Kim et al., 2007). Some good trials were achieved by using the natural products against the growth of $T$. harzianum, where the heartwood methanolic extracts of Morus alba and bark Maclura pomifera showed significant effects. The treated wood samples of Acacia saligna wood treated with wood methanolic extract of Cupressus sempervirens showed the zone of inhibition at the concentrations of 5, 10, and $20 \%$ (Mansour and Salem, 2015).

The EO of $T$. vulgaris showed fungitoxic spectrum against $A$. flavus, Fusarium oxysporum, Curvularia lunata, A. terreus, A. niger, A. fumigatus, Cladosporium herbarum, Alternaria alternata and Botryodiploidia theobromae (Kumar et al., 2008). EO of the marjoram (Lakhrissi et al., 2016) and T. vulgaris (Nikolić et al., 2014) had good activity against Candida albicans. O. majorana EO showed fungicidal effect against Verticillium dahliae and Penicillium aurantiogriseum (Rus et al., 2015). S. terebinthifolius extract with high content of phenolic compounds had good activity against the fungus Paracoccidioides brasiliensis (Johann et al., 2010) and Can. albicans (Schmourlo et al., 2005; Braga et al., 2007). Promising antifungal activity was obtained against $A$. alternate, $F$. subglutinans, C. globosum, A. niger and $T$. viride, when methanol extract/EO of $P$. rigida wood was applied to wood (Salem et al., 2016a, b).

It can be concluded from Table 5 that the $O$. $m a$ jorana $\mathrm{EO}$ and $P$. rigida wood extract had the highest activity against the tested fungi, and consequently, they were chosen for the application methods. 
..... Salem, Hamed, Mansour: Assessment of Efficacy and Effectiveness of Some Extracted...

Table 2 Inhibition percentage of mycelia growth of T. harzianum and A. niger

Tablica 2. Postotak inhibicije rasta micelija gljiva T. harzianum i A. niger

\begin{tabular}{|c|c|c|c|}
\hline \multirow{2}{*}{$\begin{array}{c}\text { Extract/EO } \\
\text { Ekstrakt / eterično ulje }\end{array}$} & \multirow{2}{*}{$\begin{array}{c}\text { Concentration, } \boldsymbol{\mu g} / \mathbf{m l} \\
\text { Koncentracija, } \mu \mathrm{g} / \mathrm{ml}\end{array}$} & \multicolumn{2}{|c|}{$\begin{array}{c}\text { Mycelia inhibition percentage } \\
\text { Postotak inhibicije micelija }\end{array}$} \\
\hline & & T. harzianum & A. niger \\
\hline \multirow{5}{*}{ T. vulgaris EO } & 0 & $0.00 \mathrm{e}$ & $0.00 \mathrm{f}$ \\
\hline & 125 & $41.11 \mathrm{~d} \pm 1.11$ & $83.33 \mathrm{c} \pm 1.11$ \\
\hline & 250 & $76.66 \mathrm{c} \pm 1.11$ & $100 \mathrm{a}$ \\
\hline & 500 & $84.44 b \pm 1.11$ & $100 \mathrm{a}$ \\
\hline & 1000 & $100 \mathrm{a}$ & $100 \mathrm{a}$ \\
\hline \multirow{5}{*}{ O. majorana $\mathrm{EO}$} & 0 & $0.00 \mathrm{e}$ & $0.00 \mathrm{f}$ \\
\hline & 125 & $100 \mathrm{a}$ & $87.77 \mathrm{~b} \pm 1.11$ \\
\hline & 250 & $100 \mathrm{a}$ & $100 \mathrm{a}$ \\
\hline & 500 & $100 \mathrm{a}$ & $100 \mathrm{a}$ \\
\hline & 1000 & $100 \mathrm{a}$ & $100 \mathrm{a}$ \\
\hline \multirow{5}{*}{ P. rigida wood extract } & 0 & $0.00 \mathrm{e}$ & $0.00 \mathrm{f}$ \\
\hline & 125 & $100 \mathrm{a}$ & $85.55 b c \pm 1.11$ \\
\hline & 250 & $100 \mathrm{a}$ & $100 \mathrm{a}$ \\
\hline & 500 & $100 \mathrm{a}$ & $100 \mathrm{a}$ \\
\hline & 1000 & $100 \mathrm{a}$ & $100 \mathrm{a}$ \\
\hline \multirow{5}{*}{$\begin{array}{l}\text { S. terebinthifolius fruit } \\
\text { extract }\end{array}$} & 0 & $0.00 \mathrm{e}$ & 0.00 \\
\hline & 125 & $46.66 \pm 1.11$ & $4.44 \mathrm{e} \pm 1.11$ \\
\hline & 250 & $82.22 \mathrm{ab} \pm 1.11$ & $14.44 \mathrm{~d} \pm 1.11$ \\
\hline & 500 & $100 \mathrm{a}$ & $100 \mathrm{a}$ \\
\hline & 1000 & $100 \mathrm{a}$ & $100 \mathrm{a}$ \\
\hline
\end{tabular}

Means with the same letters within the same column are not significantly different according to $\mathrm{LSD}_{0.05} /$ Srednje vrijednosti s istim slovom unutar istog stupca nisu značajno različite prema $L S D_{0,0 s}$.

\subsection{Weight gain $\left(\mathrm{kg} / \mathrm{m}^{3}\right)$}

3.3. Povećanje mase $\left(\mathrm{kg} / \mathrm{m}^{3}\right)$

Wood species were treated with $P$. rigida wood extract and leaf EO of $O$. majorana at the concatenation of $125 \mu \mathrm{g} / \mathrm{ml}$ for both methods (spray and immersion). Higher retentions were achieved in F. sylvatica wood with weight gain $\left(\mathrm{kg} / \mathrm{m}^{3}\right)$ of $8.16,15.33,12.08$ and $12.12 \%$, using oil spray, oil immersion, extract spray and extract immersion methods, respectively (Table 3).

\subsection{FTIR spectra of treated woods}

\subsection{FTIR spektri obrađenih uzoraka drva}

Figure 2a, b, c, and d presents the FTIR spectra of $A$. saligna, J. nigra, F. sylvatica and $P$. rigida woods, respectively, treated with either EO or extract by means of spray or immersion application methods. Treated and untreated samples exhibited the characteristic bands of wood (Owen et al., 1993; Ferraz et al., 2000; Pandey and Pitman, 2003; Tolvaj, 2009), as shown in Table 4.

For A. saligna (Figure 2a), and J. nigra (Figure 2b) nearly no changes were observed in functional groups of wood treated with EO or extract. However, wood treated with extract by immersion showed a decrease in the intensity of functional groups. No changes were found in F. sylvatica samples treated with extract or EO compared with the control sample (Figure 2c). For $P$. rigida (Figure $2 \mathrm{~d}$ ), the intensity of the absorption at the region from 350 to $1550 \mathrm{~cm}^{-1}$ was increased in samples treated with EO by immersion method and in samples treated with extract by spraying and immersion methods, which corresponds to $\mathrm{C}-\mathrm{H}$ ranged from strong-stretch to medium-weak (alkenes, vinyl and aromatics) (Sun et al., 2005).

Table 3 Wood weight gain $(W G)$ after the treatment with oil and extract by spray and immersion methods Tablica 3. Povećanje mase $(W G)$ nakon obrade uzoraka uljem i ekstraktom postupkom štrcanja i uranjanja

\begin{tabular}{|l|c|c|c|c|}
\hline \multirow{4}{*}{\begin{tabular}{c}
\multirow{4}{*}{$\begin{array}{c}\text { Wood sample } \\
\text { Uzorak drva }\end{array}$} \\
\cline { 2 - 5 }
\end{tabular}} & $\begin{array}{c}\text { O. majorana EO / Esencijalno ulje iz lišća drva } \\
\text { O. majorana }\end{array}$ & \multicolumn{2}{c|}{$\begin{array}{c}\text { P. rigida ethyl ether extract } \\
\text { Etil eterski ekstrakt iz drva P. rigida }\end{array}$} \\
\cline { 2 - 5 } & $\begin{array}{c}\text { Spray method } \\
\text { Štrcanje }\end{array}$ & $\begin{array}{c}\text { Immersion method } \\
\text { Uranjanje }\end{array}$ & $\begin{array}{c}\text { Spray method } \\
\text { Strcanje }\end{array}$ & $\begin{array}{c}\text { Immersion method } \\
\text { Uranjanje }\end{array}$ \\
\hline A. saligna & $4.66 \mathrm{ab} \pm 2.58$ & $5.71 \mathrm{~b} \pm 0.43$ & $5.29 \mathrm{~b} \pm 1.82$ & $6.33 \mathrm{~b} \pm 0.92$ \\
\hline J. nigra & $3.91 \mathrm{~b} \pm 0.31$ & $7.33 \mathrm{~b} \pm 1.66$ & $3.58 \mathrm{~b} \pm 1.21$ & $7.41 \mathrm{~b} \pm 0.81$ \\
\hline F. sylvatica & $8.16 \mathrm{a} \pm 1.33$ & $15.33 \mathrm{a} \pm 5.34$ & $12.08 \mathrm{a} \pm 0.92$ & $12.12 \mathrm{a} \pm 0.45$ \\
\hline P. rigida & $5.50 \mathrm{ab} \pm 2.34$ & $7.33 \mathrm{~b} \pm 1.44$ & $4.41 \mathrm{~b} \pm 1.82$ & $7.50 \mathrm{~b} \pm 1.47$ \\
\hline LSD 0.05 & 3.52 & 5.45 & 2.81 & 1.85 \\
\hline
\end{tabular}


a)

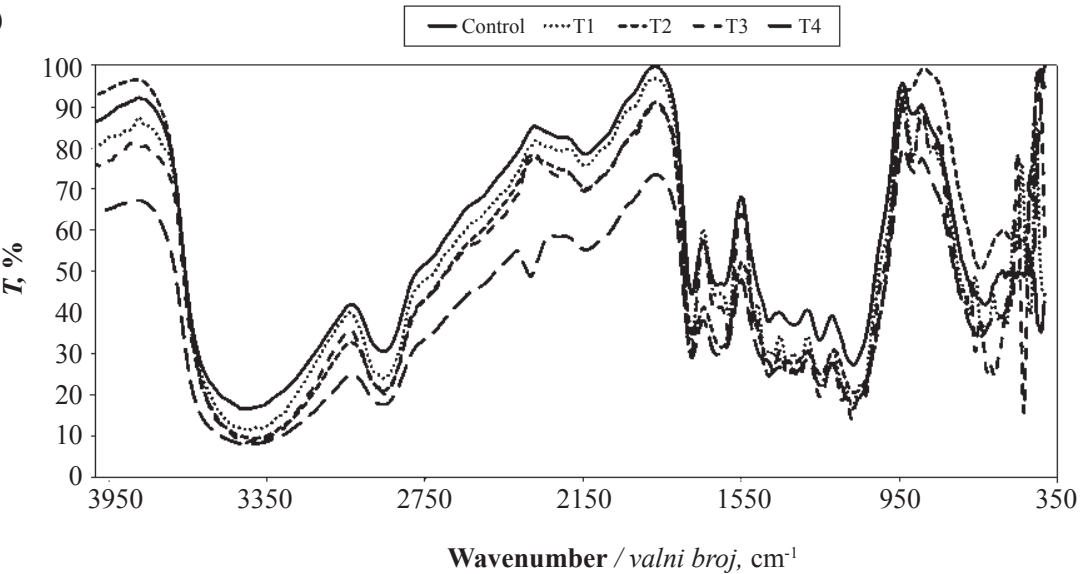

b)

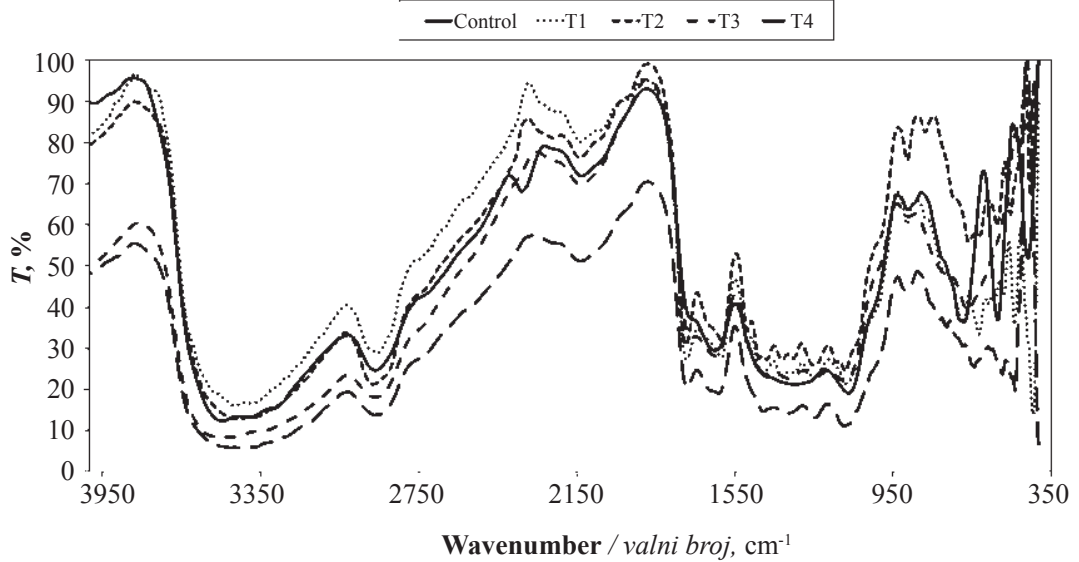

c)

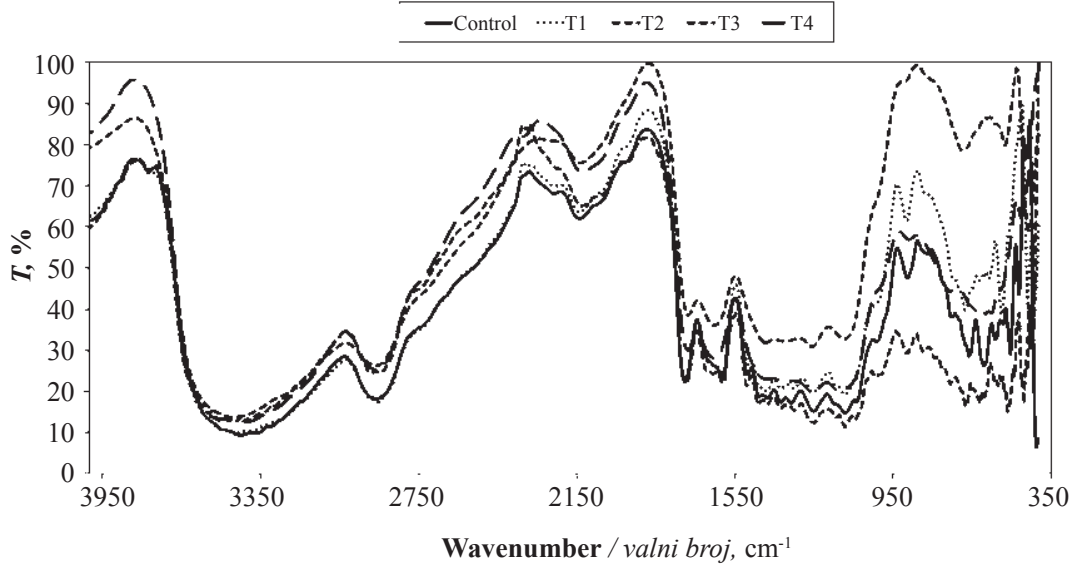

c)

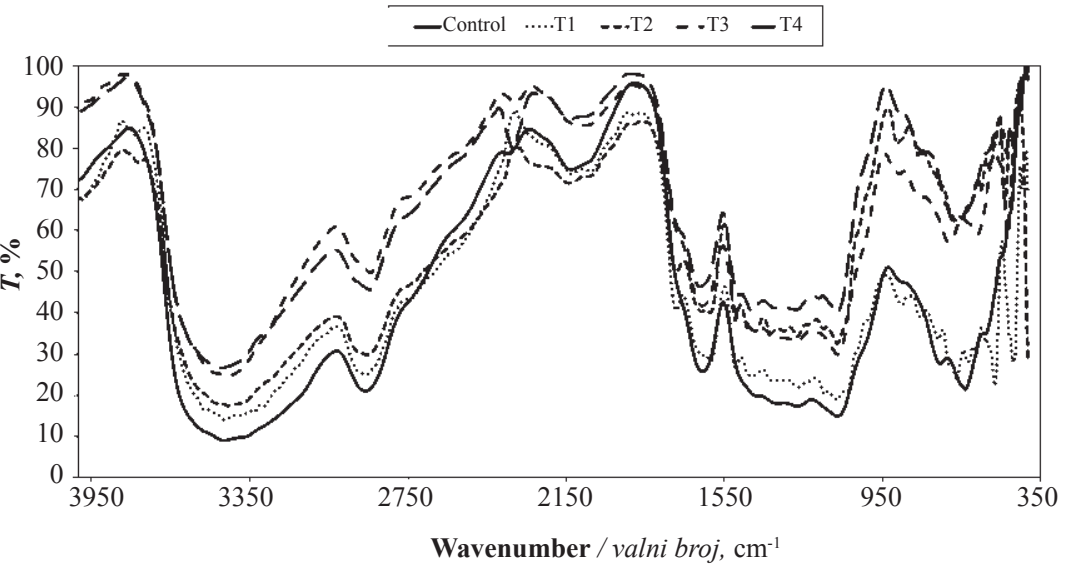

Figure 2 FTIR spectra of wood samples treated with oils and extracts with two methods T1: Oil spray; T2: Oil immersion; T3: Extract spray; T4: Extract immersion. a) A. saligna; b) J. nigra; c) F. sylvatica; d) P. rigida

Slika 2. FTIR spektri obrađenih uzoraka drva uljima i ekstraktima dvjema metodama: T1 - štrcanje ulja; T2 - uranjanje u ulje; T3 - štrcanje ekstrakta; T4 - uranjanje u ekstrakt; a) A. saligna; b) J. nigra; c) F. sylvatica; d) P. rigida 
Table 4 Functional groups in treated and untreated wood samples

Tablica 4. Funkcionalne skupine na obrađenim i neobrađenim uzorcima drva

\begin{tabular}{|c|l|l|}
\hline $\begin{array}{c}\text { Wave-number, } \mathbf{c m}^{-1} \\
\text { Valni broj, } \mathrm{cm}^{-1}\end{array}$ & \multicolumn{1}{|c|}{$\begin{array}{c}\text { Functional group bands } \\
\text { Veze funkcionalnih skupina }\end{array}$} & $\begin{array}{c}\text { Assignment } \\
\text { Pripisano spoju }\end{array}$ \\
\hline $3300-3400$ & OH stretching & Cellulose, Lignin and hemicellulose \\
\hline 2900 & $\mathrm{C}-\mathrm{H}_{2}$ asymmetric stretching & Cellulose, Lignin and hemicellulose \\
\hline 1730 & Unconjugated $\mathrm{C}=\mathrm{O}$ stretching as a shoulder & Xylan and hemicellulose \\
\hline 1633 & Absorbed O-H and conjugated $\mathrm{C}=\mathrm{O}$ & Due to oxidation of cellulose \\
\hline 1605 & $\mathrm{C}=\mathrm{C}$ stretching of the aromatic ring & Lignin (Syringyl $>$ Guaiacyl) \\
\hline 1509 & $\mathrm{C}=\mathrm{C}$ stretching of the aromatic ring & Lignin (Syringyl < Guaiacyl) \\
\hline 1434 & $\mathrm{CH}$ scissor vibration & Cellulose (crystallized and amorphous) \\
\hline 1370 & $\mathrm{C}-\mathrm{H}$ deformation & In cellulose and hemicellulose \\
\hline 1326 & $\mathrm{C}-\mathrm{H}$ vibration in cellulose and C-O vibration & In syringyl derivatives. \\
\hline 1248 & Syringyl ring and C-O stretch & In lignin (Syringyl) and xylan. \\
\hline $1150-1265$ & $\mathrm{C}-\mathrm{O}-\mathrm{C}$ bridge oxygen stretching & Cellulose \\
\hline 1110 & $\mathrm{C}-\mathrm{O}$ stretching & Cellulose and hemicellulose \\
\hline 894 & $\mathrm{C}-\mathrm{H}$ deformation & cellulose \\
\hline 670 & $\mathrm{COH}$ out-of-plane bending & cellulose \\
\hline & & \\
\hline
\end{tabular}

Table 5 Chromatic parameters of samples measured in the $L^{*}, a^{*}, b^{*}$ color system

Tablica 5. Kromatski parametri uzoraka izmjerenih u sustavu boja $L^{*}, a^{*}, b^{*}$

\begin{tabular}{|c|c|c|c|c|}
\hline \multirow{3}{*}{$\begin{array}{c}\text { Wood sample } \\
\text { Uzorak drva }\end{array}$} & \multicolumn{4}{|c|}{$\Delta E^{*}$} \\
\hline & \multicolumn{2}{|c|}{$\begin{array}{c}\text { O. majorana EO } \\
\text { Esencijalno ulje iz lišća drva O. majorana }\end{array}$} & \multicolumn{2}{|c|}{$\begin{array}{c}\text { P. rigida ethyl ether extract } \\
\text { Etil eterski ekstrakt iz drva P. rigida }\end{array}$} \\
\hline & $\begin{array}{l}\text { Spray method } \\
\text { Štrcanje }\end{array}$ & $\begin{array}{c}\text { Immersion method } \\
\text { Uranjanje }\end{array}$ & $\begin{array}{l}\text { Spray method } \\
\text { Strcanje }\end{array}$ & $\begin{array}{c}\text { Immersion method } \\
\text { Uranjanje }\end{array}$ \\
\hline A. saligna & 1.06 & 1.29 & 0.64 & 1.38 \\
\hline J. nigra & 0.50 & 0.52 & 2.13 & 2.28 \\
\hline F. sylvatica & 0.76 & 0.48 & 1.89 & 2.52 \\
\hline P. rigida & 0.91 & 0.78 & 1.59 & 2.50 \\
\hline
\end{tabular}

\subsection{Chromatic alternation of treated wood samples}

3.5. Kromatska svojstva obrađenih uzoraka drva

The color change measurements presented in Table 5 showed that the wood samples treated with $O$. majorana EO by both methods (spray and immersion methods) had the lowest $\Delta \mathrm{E}$. These lowest values of $\Delta \mathrm{E}$ suggested that the treatments with $125 \mu \mathrm{g} / \mathrm{ml} \mathrm{kept}$ the wood at nearly its original color.

\subsection{SEM examination}

\subsection{SEM ispitivanje}

Samples that did not show any changes in previous investigations after treatment and aging were examined by SEM to evaluate their distribution and penetration in the wood surface. So, wood samples treated with O. majorana EO showed good results. Application of oils and extracts by immersion apparently bring about an effect of increasing the distribution and penetration of EO in the wood surface. Also, the results revealed that the EO penetrated and distributed in a better way on the surface of $A$. saligna and $F$. sylvatica (Figures 3 and 4) than on the surface of J. nigra and $P$. rigida (Figures 5 and 6). No drastic changes were seen in the micrographs; on the contrary the EO treatment apparently achieved the consolidation of wood tissue. The microscopic investigation proved that the success and effectiveness of the treatment can be attributed to the wood type and the application method. However, samples treated by immersion have considerably higher absorption value than the ones treated by spraying, as confirmed by weighing samples before and after treatments.

\section{CONCLUSIONS 4. ZAKLJUČAK}

In the present study, two extracts (ethyl ether extracts of $S$. terebinthifolius ripened fruits and $P$. rigida heartwood) and two essential oils (T. vulgaris and $O$. majorana leaves) were used to assess their antifungal activity against $T$. harzianum and $A$. niger. The results showed that $O$. majorana EO and $P$. rigida wood extract had the highest activity against both fungi and were chosen for the application on wood samples of $A$. saligna, F. sylvatica, J. nigra and $P$. rigida. The increases in color changes of wood samples due to $P$. rigida wood extract suggest that it is unsuitable for application on wood. Significant penetration of $O$. majorana $\mathrm{EO}$ in wood structure especially by immersion method not only increases its efficacy as a bio-fungicide but also consolidates the wood tissue. Overall, however, O. majorana oil appears to be the most promising. Future experiments may examine mixing these natural materials with natural polymers used as wood consolidants to enhance their anti-fungal properties. 


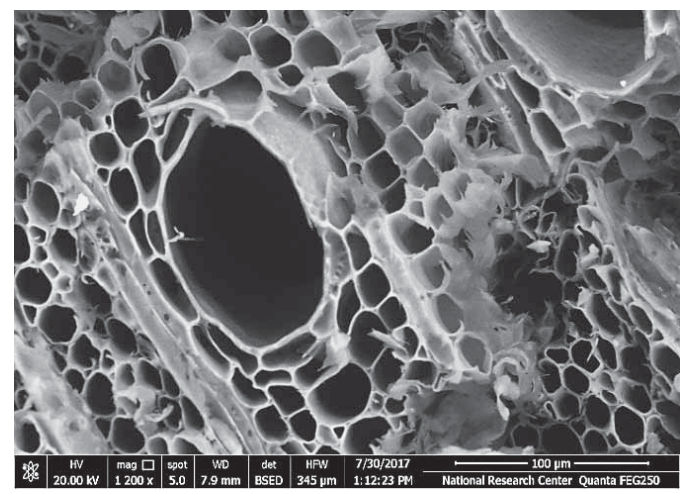

a)

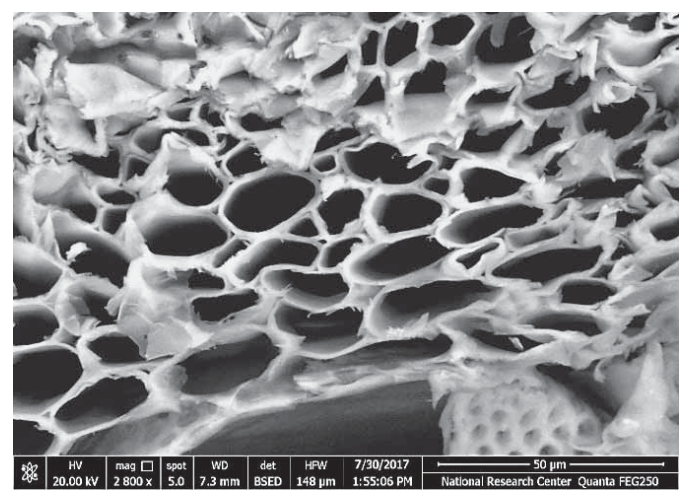

c)

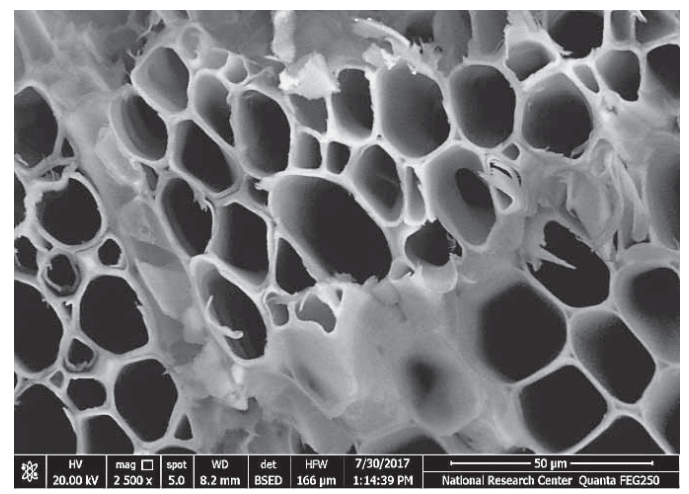

b)

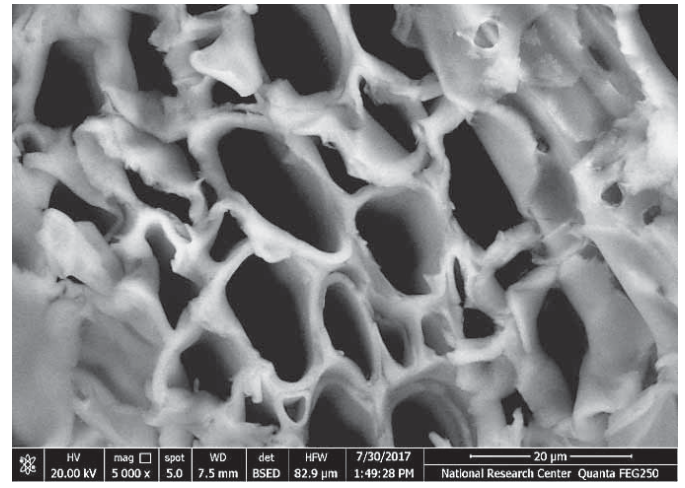

d)

Figure 3 SEM micrographs of $A$. saligna samples treated with $O$. majorana oil, a, b - treated by spraying; c, $\mathrm{d}$ - treated by immersion

Slika 3. SEM mikrografije uzoraka drva A. saligna obrađenih uljem drva O. majorana $(\mathrm{a}, \mathrm{b}$ - obrađeni štrcanjem; c, b obrađeni uranjanjem)

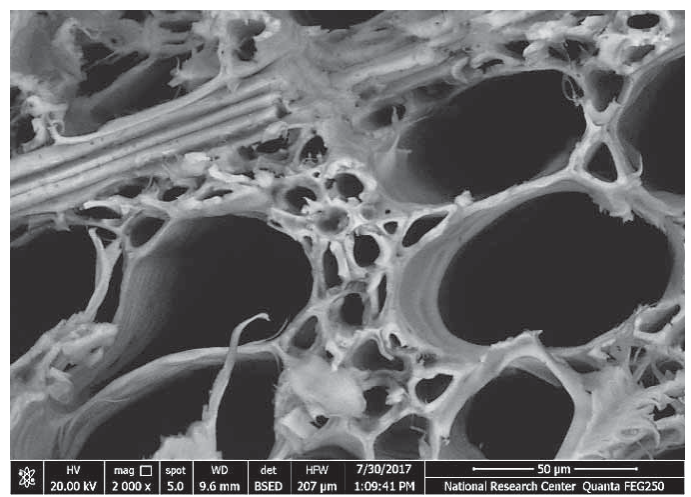

a)

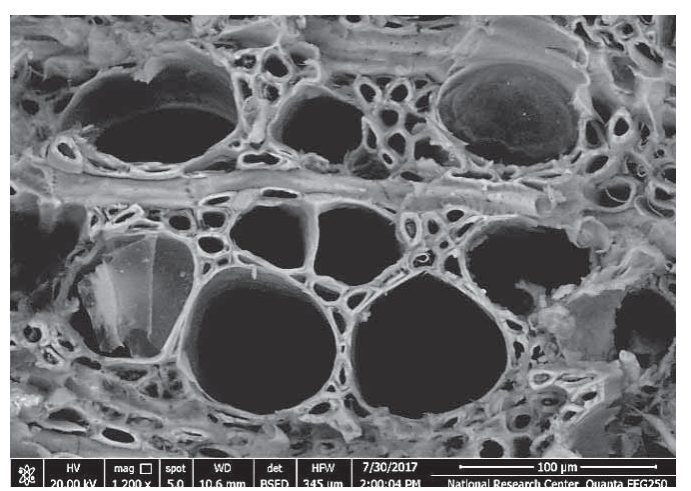

c)

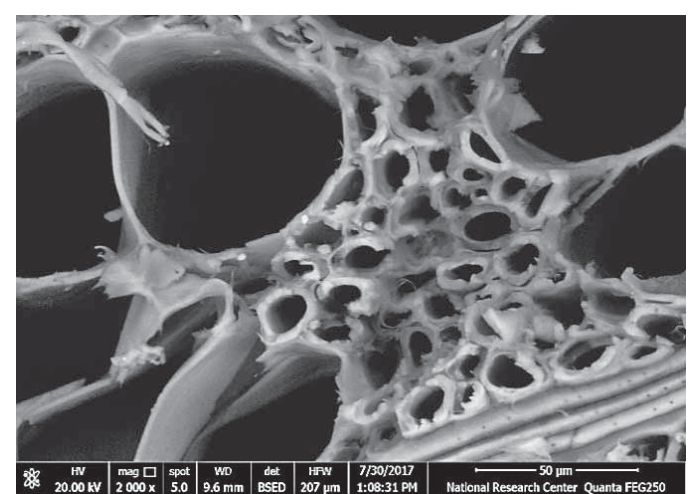

b)

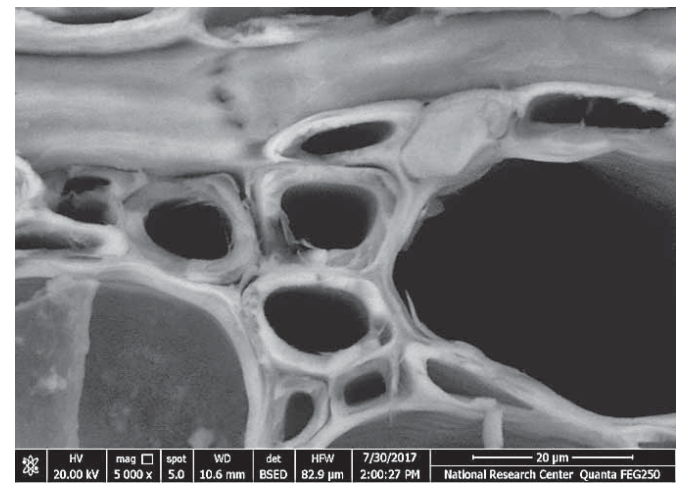

d)

Figure 4 SEM micrographs of F. sylvatica samples treated with $O$. majorana oil, a, b - treated by spraying; c, d - treated by immersion

Slika 4. SEM mikrografije uzoraka drva F. sylvatica obrađenih uljem drva O. majorana $(\mathrm{a}, \mathrm{b}$ - obrađeni štrcanjem; $\mathrm{c}, \mathrm{b}-$ obrađeni uranjanjem) 
..... Salem, Hamed, Mansour: Assessment of Efficacy and Effectiveness of Some Extracted...

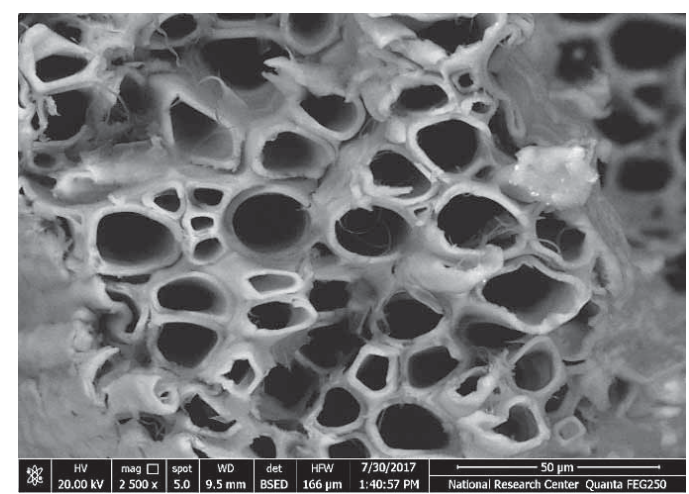

a)

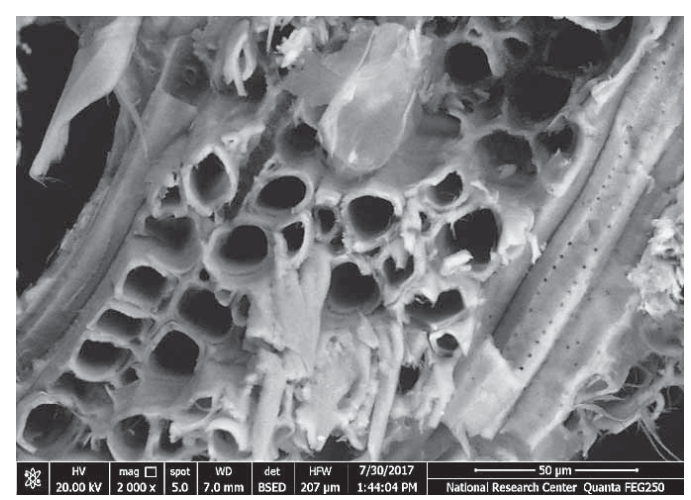

c)

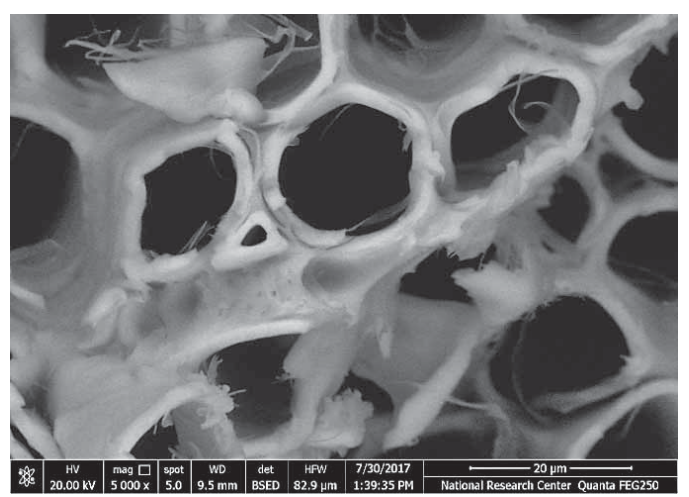

b)

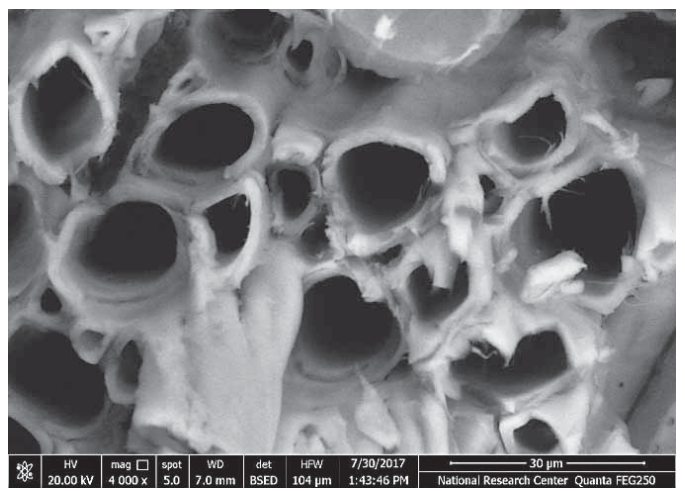

d)

Figure 5 SEM micrographs of J. nigra samples treated with $O$. majorana oil, a, b - treated by spraying; c, d - treated by immersion

Slika 5. SEM mikrografije uzoraka drva J. nigra obrađenih uljem drva O. majorana (a, b - obrađeni štrcanjem; c, b obrađeni uranjanjem)

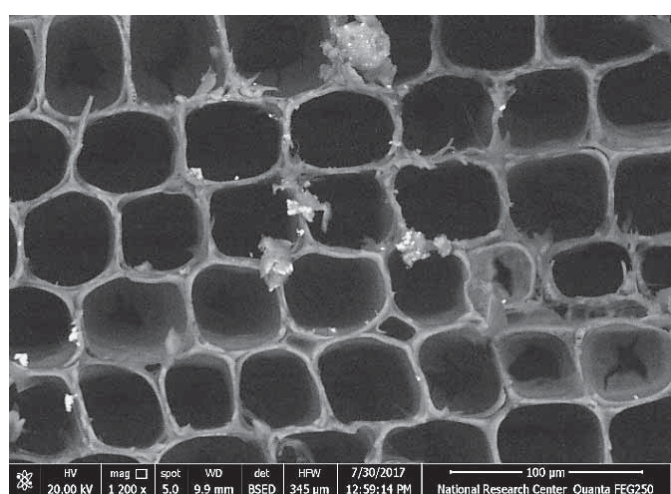

a)

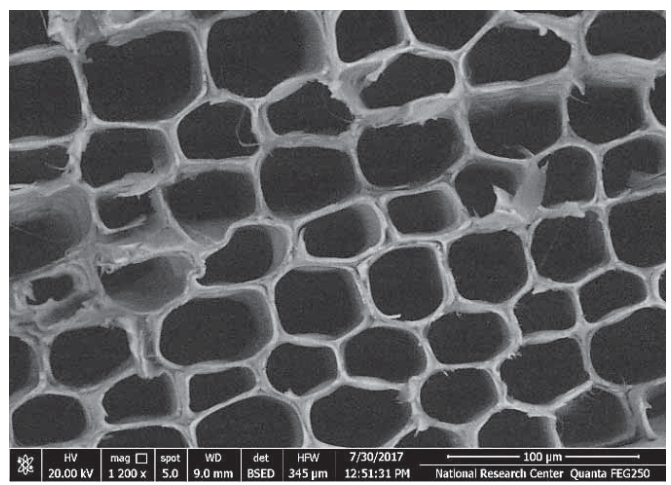

c)

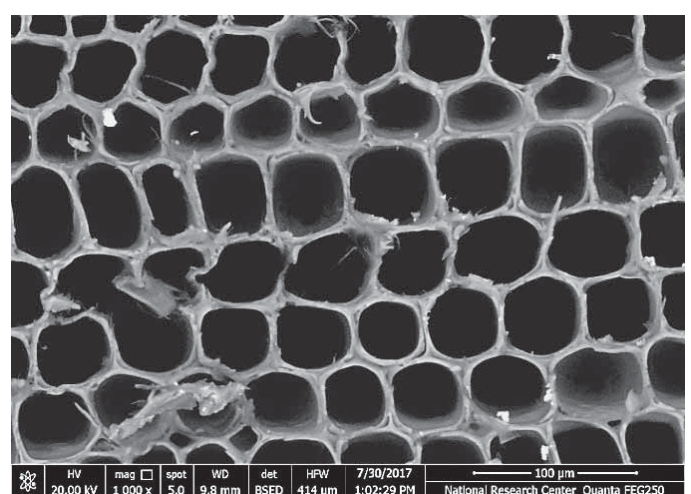

b)

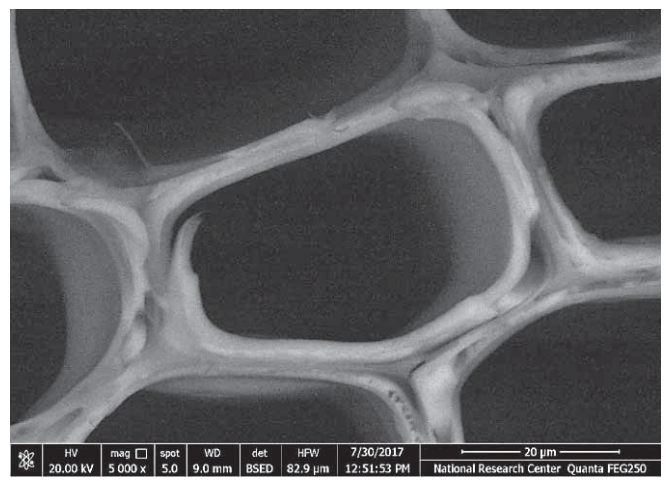

d)

Figure 6 SEM micrographs of $P$. rigida samples treated with $O$. majorana oil, a, b - treated by spraying; c, d - treated by immersion

Slika 6. SEM mikrografije uzoraka drva P. rigida obrađenih uljem drva O. majorana (a, b - obrađeni štrcanjem; c, b obrađeni uranjanjem) 


\section{REFERENCES}

\section{LITERATURA}

1. Al-Asmari, A. K.; Athar, M. T.; Al-Faraidy, A. A.; Almuhaiza, M. S., 2017: Chemical composition of essential oil of Thymus vulgaris collected from Saudi Arabian market. Asian Pacific Journal of Tropical Biomedicine, 7 (2): 147-150. https://doi.org/10.1016/j.apjtb.2016.11.023.

2. Al-Huqail, A. A.; Behiry, S. I.; Salem, M. Z. M.; Ali, H. M.; Siddiqui, M. H.; Salem, A. Z. M., 2019: Antifungal, antibacterial, and antioxidant activities of Acacia saligna (Labill.) H. L. Wendl. flower extract: HPLC analysis of phenolic and flavonoid compounds. Molecules, 24(4): 700. https://doi.org/10.3390/molecules24040700.

3. Arslan, M.; Dervis, S.; 2010: Antifungal activity of essential oils against three vegetative-compatibility groups of Verticillium dahlia. World Journal of Microbiology and Biotechnology, 26 (10): 1813-1821. https://doi.org/10.1007/s11274-010-0362-2.

4. Ballester-Costa, C.; Sendra, E.; Fernández-López, J.; Pérez-Álvarez, J. A.; Viuda-Martos, M., 2013: Chemical composition and in vitro antibacterial properties of essential oils of four Thymus species from organic growth. Industrial Crops and Products, 50 (10): 304-311. https://doi.org/10.1016/j.indcrop.2013.07.052.

5. Behiry, S. I.; Okla, M. K.; Alamri, S. A.; EL-Hefny, M.; Salem, M. Z. M.; Alaraidh, I. A.; Ali, H. M.; Al-Ghtani, S. M.; Monroy, J. C.; Salem, A. Z. M., 2019: Antifungal and antibacterial activities of Musa paradisiaca L. peel extract: HPLC analysis of phenolic and flavonoid contents. Processes, 7 (4): 215. https://doi.org/10.3390/pr7040215.

6. Blanchette, R. A.; Farrell, R. L.; Burnes, T. A., 1992: Biological control of pitch in pulp \& paper production by Ophiostoma piliferum. Tappi, 75: 102-106.

7. Braga, F. G.; Bouzada, M. L.; Fabri, R. L.; de O Matos, M.; Moreira, F. O.; Scio, E.; Coimbra, E. S., 2007: Antileishmanial and antifungal activity of plants used in traditional medicine in Brazil. Journal of Ethnopharmacology, 111 (2): 396-402.

https://doi.org/10.1016/j.jep.2006.12.006.

8. Breuil, C., 1998: Wood as a nutritional resource for staining fungi. In: Biology and Prevention of Sapstain. Forest Products Society, Madison, pp. 1-6.

9. Busatta, C.; Vidala, R. S.; Popiolskia, A. S.; Mossia, A. J.; Dariva, C.; Rodrigues, M. R. A.; Corazza, F. C.; Corazza, M. L.; Oliveira J. V.; Cansiana, R. L., 2008: Application of Origanum majorana L. essential oil as an antimicrobial agent in sausage. Food Microbiology, 25 (1): 207-211. https://doi.org/10.1016/j.fm.2007.07.003.

10. Daniel, G., 2003: Microview of wood under degradation by bacteria and fungi. In Proceedings of ACS Symposium Series 845: Wood deterioration and Preservation, Goodell, B.; Nicholas, D. D.; Schultz, T. P. (eds.), Washington DC, USA, pp. 34-72.

11. De Angelis, M; Romagnoli, M.; Vek, V.; Poljanšek, I.; Oven, P.; Thaler, N.; Lesar, B.; Kržišnik, D.; Humar, M., 2018: Chemical composition and resistance of Italian stone pine (Pinus pinea L.) wood against fungal decay and wetting. Industrial Crops and Products, 117: 187196. https://doi.org/10.1016/j.indcrop.2018.03.016.

12. Domsch, K. H.; Gams, W.; Anderson, T. H., 2007: Compendium of Soil Fungi, second ed. IHW-Verlag, Eching, Germany. Taxonomically revised by W. Gams.

13. Fabbri, A. A.; Ricelli, A.; Brasini, S.; Fanelli, C., 1997: Effect of different antifungals on the control of paper biodeterioration caused by fungi. International Biodeteriora- tion \& Biodegradation, 39 (1): 61-65. https://doi. org/10.1016/S0964-8305(97)00001-2.

14. Fazio, A. T.; Papinutti, L.; Gómez, B. A.; Parera, S. D.; Rodríguez Romero, A., Siracusano, A. G.; Maier, M. S., 2010: Fungal deterioration of a Jesuit South American polychrome wood sculpture. International Biodeterioration \& Biodegradation, 64 (8): 694-701. https://doi. org/10.1016/j.ibiod.2010.04.012.

15. Ferraz, A. U.; Baeza, J.; Rodriguez, J.; Freer, J.; 2000: Estimating the chemical composition of biodegraded pine and eucalyptus wood by DRIFT spectroscopy and multivariate analysis. Bioresource Technology, 74 (3): 201-212. https://doi.org/10.1016/S0960-8524(00)00024-9.

16. George, W., 1995: Hand Book of Material Weathering, $2^{\text {nd }}$ ed. Chem Tec, Ontario, Canada.

17. Ghosh, S. C.; Mai, C.; Militz, H., 2008: The Efficacy of Commercial Silicones against Blue Stain and Mould Fungi in Wood. The International Research Group on Wood Protection (Istanbul, Turkey), IRG/WP 08-30471, 17 p.

18. Goktas, O.; Baysal, E.; Ozen, E.; Mammadov, R.; Duru, M. E., 2008: Decay resistance and color stability of wood treated with Juglans regia extract. Wood Research, 53(3): 27-36.

19. Ibrahim, F. A.; Bellail, A. A.; Hamad, A. M.; MecheraraIdjeri, S., 2017: Antimicrobial Activities and chemical composition of the essential oil of Origanum majorana L. growing in Libya. Ijppr. Human, 8 (3): 1-11.

20. Imelouane, B.; Amhamdi, H.; Wathelet, J. P.; Ankit, M.; Khedid, K.; El-Bachiri, A., 2009: Chemical composition and antimicrobial activity of essential oil of thyme (Thymus vulgaris) from eastern Morocco. International Journal of Agriculture and Biology, 11 (2): 205-208.

21. Jeloková, E.; Šindler, J., 1997: Influence of beech and acacia wood extractives on activity of wood-destroying fungi. In Proseedings of $1^{\text {th }}$ Symposium e Drevoznehodnocujúce huby, 97, 133-139. TU Zvolen.

22. Jeloková, E.; Šindler, J., 2001: Testing of some chemical compounds for wood protection. Drevo, 56: 137-138.

23. Johann, S.; Cisalpino, P. S.; Watanabe, G. A.; Cota, B .B.; de Siqueira, E. P.; Pizzolatti, M. G.; Zani, C. L.; de Resende, M. A., 2010: Antifungal activity of extracts of some plants used in Brazilian traditional medicine against the pathogenic fungus Paracoccidioides brasiliensis. Pharmaceutical Biology, 48 (4): 388-396. https://doi.org/10.3109/13880200903150385.

24. Kassem, M. E. S.; El-Desoky, S. K.; Sharaf, M., 2004: Biphenyl esters and bioflavonoids from the fruits of Schinus terebinthifolius. Chemistry of Natural Compounds, 40 (5): 447-450. https://doi.org/10.1007/s10600-005-0008-z.

25. Kerner-Gang, W.; Schneider, R., 1969: Von optischen Gläsern isolierte Schimmelpilze. Mater. Org. 4: 281-296.

26. Kim, J.-J.; Kang, S.-M.; Choi, Y.-S.; Kim, G.-H., 2007: Microfungi potentially disfiguring CCA-treated wood. International Biodeterioration \& Biodegradation, 60 (3): 197-201. https://doi.org/10.1016/j.ibiod.2007.05.002.

27. Kiran, B.; Raveesha, K. A., 2006: Antifungal activity of seed extract of Psoralea corylifolia L. Research in Plant Disease, 20: 213-215.

28. Kumar, A.; Shukla, R.; Singh, P.; Prasad, C. S.; Dubey, N. K., 2008: Assessment of Thymus vulgaris L. essential oil as a safe botanical preservative against post-harvest fungal infestation of food commodities. Innovative Food Science and Emerging Technologies, 9 (4): 575-580. https://doi.org/10.1016/j.ifset.2007.12.005.

29. Lakhrissi, B.; Boukhraz, A.; Barrahi, M.; Hartiti, H. E. L.; Ouhssine, M., 2016: Antifungal activity of essential oil of Oregano (Origanum Vulgare), Marjoram (Origa- 
num Majorana) and synergy of two essential oils against Candida albicans. International Journal of Innovative Research in Science, Engineering and Technology 3 (12): 14-17.

30. Li, Q.; Lin, J.-G.; Liu, J., 2013: Decay resistance of wood treated with extracts of Cinnamomum camphora xylem. BioResources, 8 (3): 4208-4217.

31. Lima, M. R. F.; Luna, J. S.; Santos, A. F.; Andrade, M. C. C.; Sant'ana, A. E .G.; Genet, J. P.; Marquez, B.; Neuville, L.; Moreau, N., 2006: Anti-bacterial activity of some Brazilian medicinal plants. Journal of Ethnopharmacology, 105 (1-2): 137-147.

https://doi.org/10.1016/j.jep.2005.10.026.

32. Ljaljević Grbić, M.; Stupar, M.; Vukojević, J.; Maričić, I.; Bungur, N., 2013: Molds in museum environments: biodeterioration of art photographs and wooden sculptures. Archives of Biological Science Belgrade, 65(3): 955-962. https://doi.org/10.2298/ABS1303955G.

33. Lloyd, H. A.; Jaouni, T. M.; Evans, S. L.; Morton, J. F., 1977: Terpenes of Schinus terebinthifolius. Phytochemistry, 16: 1301-1302.

34. Mansour, M. M.; Salem, M. Z. M., 2015: Evaluation of wood treated with some natural extracts and Paraloid B-72 against the fungus Trichoderma harzianum: wood elemental composition, in-vitro and application evidence. International Biodeterioration \& Biodegradation, 100 (5): 62-69. https://doi.org/10.1016/j.ibiod.2015.02.009.

35. Mansour, M. M. A.; Salem, M. Z. M.; Khamis, M. H.; Ali, H. M., 2015a. Natural durability of Citharexylum spinosum and Morus alba woods against three mold fungi. BioResources, 10 (3): 5330-5344.

36. Mesquita, N.; Portugal, A.; Videira, S.; Rodríguez-Echeverría, S.; Bandeira, A. M. L.; Santos, M. J. A.; Freitas, H., 2009: Fungal diversity in ancient documents. A case study on the archive of the University of Coimbra. International Biodeterioration \& Biodegradation, 63 (5): 626629. https://doi.org/10.1016/j.ibiod.2009.03.010.

37. Mohamed, W. A.; Mansour, M. M. A.; Salem, M. Z. M., 2019. Lemna gibba and Eichhornia crassipes extracts: clean alternatives for deacidification, antioxidation and fungicidal treatment of historical paper. Journal of Cleaner Production, 219: 846-855.

https://doi.org/10.1016/j.jclepro.2019.02.097.

38. Nikolić, M.; Glamočlija, J.; Ferreira, I. C. F. R., Calhelha R. C.; Fernandes, Â.; Marković, T.; Marković, D.; Giweli, A.; Soković, M., 2014: Chemical composition, antimicrobial, antioxidant and antitumor activity of Thymus serpyllum L., Thymus algeriensis Boiss. and Reut and Thymus vulgaris L. essential oils. Industrial Crops and Products, 52 (1): 183-190. https://doi.org/10.1016/j.indcrop.2013.10.006.

39. NIST/EPA/NIH Mass Spectral Library (NIST 11) and NIST Mass Spectral Search Program (Version 2.0g), May 2011.

40. Oberacher, H., 2011: Wiley Registry of Tandem Mass Spectral Data, MSforID. Hoboken: John Wiley \& Sons Inc., 2011.

41. Obanda, D. N.; Shupe, T. F.; Catallo, W. J., 2008: Resistance of Trichoderma harzianum to the biocide tebuconazol - proposed biodegradation pathways. Holzforschung, 62 (5): 613-619.

https://doi.org/10.1515/HF.2008.098.

42. Owen, J. A.; Owen, N. L.; Feist, W. C., 1993: Scanning electron microscope and infrared studies of weathering in southern pine. Journal of Molecular Structure, 300: 105114. https://doi.org/10.1016/0022-2860(93)87010-7.
43. Pandey, K. K.; Pitman, A. J., 2003: FTIR studies of the changes in wood chemistry following decay by brownrot and white-rot fungi. International Biodeterioration \& Biodegradation, 52: 151-160.

https://doi.org/10.1016/S0964-8305(03)00052-0.

44. Philp, R. W.; Bruce, A.; Munro, A. G., 1995: The effect of water soluble scats pine (Pinus sylvestris L.) and Sitka Spruce [Picea sitchensis (Bong.) Cam] heartwood and sapwood extracts on the growth of selected Trichoderma species. International Biodeterioration \& Biodegradation, 35 (5): 355-367. https://doi.org/10.1016/0964-8305(95)00053-9.

45. Qi, W.; Jellison, J., 2004: Characterization of a transplasma membrane redox system of the brown rot fungus Gloeophyllum trabeum. International Biodeterioration \& Biodegradation, 53 (1): 37-42. https://doi.org/10.1016/j.ibiod.2003.09.002.

46. Ramos, S.; Rojas, L. B.; Lucena, M. E.; Meccia, G.; Usubillaga, A., 2011: Chemical composition and antibacterial activity of Origanum majorana L. essential oil from the Venezuelan Andes. Journal of Essential Oil Research, 23 (5): 45-49. https://doi.org/10.1080/10412905.2011.9700481.

47. Rus, C. F.; Pop, G.; Alexa, E.; Şumălan, R. M.; Copolovici, D. M. M., 2015: Antifungal activity and chemical composition of Origanum majorana L. essential oil. Research Journal of Agriculture and Biological Sciences, 47 (2): 179-185.

48. Salem, M. Z. M., 2016: EDX measurements and SEM examination of surface of some imported woods inoculated by three mold fungi. Measurement, 86 (5): 301309. https://doi.org/10.1016/j.measurement.2016.03.008.

49. Salem, M. Z. M.; Mansour, M. M. A.; Mohamed, W. S.; Ali, H. M.; Hatamleh, A. A., 2017: Evaluation of the antifungal activity of treated Acacia saligna wood with Paraloid B-72/ $\mathrm{TiO}_{2}$ nanocomposites against the growth of Alternaria tenuissima, Trichoderma harzianum, and Fusarium culmorum. BioResources, 12 (4): 7615-7627.

50. Salem, M. Z. M.; Zidan, Y. E.; Mansour, M. M. A.; El Hadidi, N. M. N.; Abo Elgat, W. A. A., 2016a: Antifungal activities of two essential oils used in the treatment of three commercial woods deteriorated by five common mold fungi. International Biodeterioration \& Biodegradation, 106 (1): 88-96. https://doi.org/10.1016/j.ibiod.2015.10.010.

51. Salem, M. Z. M.; Zidan, Y. E.; Mansour, M. M. A.; El Hadidi, N. M. N.; Abo Elgat, W. A. A., 2016b: Evaluation of usage three natural extracts applied to three commercial wood species against five common molds. International Biodeterioration \& Biodegradation, 110 (5): 206226. https://doi.org/10.1016/j.ibiod.2016.03.028.

52. Salem, M. Z. M.; Zayed, M. Z.; Ali, H. M.; Abd El-Kareem, M. S. M., 2016c. Chemical composition, antioxidant and antibacterial activities of extracts from Schinus molle L. wood branch growing in Egypt. Journal of Wood Science, 62 (6): 548-561. https://doi.org/10.1007/s10086-016-1583-2.

53. Salem, M. Z. M.; Ali, H. M.; El-Shanhorey, N. A.; AbdelMegeed, A., 2013: Evaluation of extracts and essential oil from Callistemon viminalis leaves: antibacterial and antioxidant activities, total phenolic and flavonoid contents. Asian Pacific Journal of Tropical Medicine, 6 (10): 785791. https://doi.org/10.1016/S1995-7645(13)60139-X.

54. Salem, M. Z. M.; EL-Hefny, M.; Ali, H. M.; Elansary, H. O.; Nasser, R. A.; El-Settawy, A. A. A.; El Shanhorey, N.; Ashmawy, N. A.; Salem, A. Z. M., 2018: Antibacterial activity of extracted bioactive molecules of Schinus ter- 
ebinthifolius ripened fruits against some pathogenic bacteria. Microbial Pathogenesis, 120 (7): 119-127. https://doi.org/10.1016/j.micpath.2018.04.040.

55. Salem, M. Z. M.; Behiry, S. I.; EL-Hefny, M., 2019b: Inhibition of Fusarium culmorum, Penicillium chrysogenum and Rhizoctonia solani by n-hexane extracts of three plant species as a wood-treated oil fungicide. Journal of Applied Microbiology, 126 (6): 1683-1699. https://doi.org/10.1111/jam.14256.

56. Salem, M. Z. M.; Mansour, M. M. A.; Elansary, H. O., 2019b. Evaluation of the effect of inner and outer bark extracts of Sugar Maple (Acer saccharum var. saccharum) in combination with citric acid against the growth of three common molds. Journal of Wood Chemistry and Technology, 39 (2): 136-147.

https://doi.org/10.1080/02773813.2018.1547763.

57. Schmidt, O., 2006: Wood and Tree Fungi: Biology, Damage, Protection and Use. Springer-Verlag, Berlin, Germany.

58. Schmourlo, G.; Mendonça-Filho, R. R.; Alviano, C. S.; Costa, S. S., 2005: Screening of antifungal agents using ethanol precipitation and bioautography of medicinal and food plants. Journal of Ethnopharmacology, 96 (3): 563 568. https://doi.org/10.1016/j.jep.2004.10.007.

59. Sun, X. F.; Xu, F.; Sun, R. C.; Fowler, P.; Baird, M. S., 2005: Characteristics of degraded cellulose obtained from steam-exploded wheat straw. Carbohydrate Research, 340 (1): 97-106. https://doi.org/10.1016/j.carres.2004.10.022.

60. Strzelczyk, A. B.; Kuroczkin, J.; Krumbein, W. E., 1987: Studies on the microbial degradation of ancient leather bookbindings. Part 2. International Biodeterioration, 23 (1): 3-27. https://doi.org/10.1016/0265-3036(87)90039-X.

61. Tolvaj, L., 2009: Monitoring of photodegradation for wood by infrared spectroscopy. International Conference on Wooden Cultural Heritage: Evaluation of Deterioration and Management of Change (Hamburg/Germany). http://real.mtak.hu/24589/.

62. Van Meel, P. A.; Erich, S. J. F.; Huinink, H. P.; Kopinga K.; De Jong, J.; Adan, O. C. G., 2011: Moisture transport in coated wood. Progress in Organic Coatings, 72: 686694. https://doi.org/10.1016/j.porgcoat.2011.07.011.

63. Vera, R. R.; Chane-Ming, J., 1999: Chemical composition of the essential oil of marjoram (Origanum majorana $\mathrm{L}$.) from Reunion Island. Food Chemistry, 66 (2): 143-145. https://doi.org/10.1016/S0308-8146(98)00018-1.
64. Verma, J.; Dubey, N. K., 1999: Prospectives of botanical and microbial products as pesticides of tomorrow. Current Science, 76: 172-179.

65. Viitanen, H.; Ritschkoff, A.-C., 1991: Mould Growth in Pine and Spruce Sapwood in Relation to Air Humidity and Temperature. Swed. Univ. Agric. Sci. Dept. Forest Prod., Uppsala-Sweden. Report No. 221.

66. Viuda-Martos, M.; El Gendy, A. E.; Sendra, E.; Fernández-López, J.; El Razik, K. A. A.; Omer, E. A.; PérezAlvarez, J. A., 2010: Chemical composition and antioxidant and anti-Listeria activities of essential oils obtained from some Egyptian plants. Journal of Agricultural and Food Chemistry, 58 (16): 9063-9070. https://doi.org/10.1021/jf101620c.

67. Wang, C. J. K.; Zabel, R. A. (eds.), 1990: Identification Manual for Fungi from Utility Poles in the Eastern United States. Allen Press, Lawrence, Kansas.

68. Wang, S. Y.; Chen, P. F.; Chang, S. T., 2005: Antifungal activities of essential oils and their constituents from indigenous cinnamon (Cinnamomum osmophloeum) leaves against wood decay fungi. Bioresource Technology, 96 (7): $813-818$ https://doi.org/10.1016/j.biortech.2004.07.010.

69. Xu, K.; Feng, J.; Zhong, T.; Zheng, Z.; Chen, T., 2015: Effects of volatile chemical components of wood species on mould growth susceptibility and termite attack resistance of wood plastic composites. International Biodeterioration \& Biodegradatio, 100 (5): 106-115. https://doi.org/10.1016/j.ibiod.2015.02.002.

70. Zabel, R. A.; Morrell, J. J., 1992: Wood Microbiology Decay and Its Prevention. Academic Press, London.

71. Žlahtič, M.; Humar, M., 2017: Influence of Artificial and Natural Weathering on the Moisture Dynamic of Wood. BioResources, 12 (1): 117-142.

https://doi.org/10.15376/biores.12.1.117-142.

\section{Corresponding address:}

Assoc. Prof. MOHAMED Z. M. SALEM, Ph.D.

Alexandria University

Forestry and Wood Technology Department

Faculty of Agriculture (EL-Shatby)

Alexandria, EGYPT

e-mail: Mohamed-salem@alexu.edu.eg 